Nordisk Tidsskrift for Kriminalvidenskab 2007

\title{
HAR SAMFUNDSTJENESTE EN PRÆVENTIV EFFEKT?
}

Af fuldmægtig, Ph.D. Susanne Clausen

The Community Service Programme (CS) was introduced in Denmark in 1982. The programme offers an alternative to incarceration in which offenders are sentenced to anywhere from 30 to 240 hours of unpaid work benefiting the community. The article presents results from an effect evaluation which is part of a dissertation about the Danish CS. The effect evaluation examines whether offenders sentenced to CS have lower rates of recidivism than offenders sentenced to imprisonment. The evaluation is conducted with two types of offenders examined within two "natural experiments". The first natural experiment is based on a change in the law that occurred in 2000 which made traffic code offenders (primarily drunk drivers) eligible for CS. The second natural experiment emanates from a change in judicial policy in the late 1990s after which the courts more frequently sentenced violent offenders to CS. The evaluation shows that after controlling for criminal history and socio-economic circumstances, some offenders sentenced to CS have lower rates of recidivism than offenders sentenced to prison. For example, a positive preventive effect of $C S$ was clearly apparent among young offenders sentenced for traffic offences. Among those sentenced for violent offences, CS was associated with a lower rate of recidivism among the unemployed, i.e. unemployed offenders who served CS had lower rates of recidivism than unemployed offenders who went to prison. ${ }^{*}$

\section{Indledning}

Den danske samfundstjenesteordning består i, at en person kan dømmes til at udføre ulønnet, samfundsnyttigt arbejde i 30-240 timer. Samfundstjeneste gives som vilkår til en betinget dom og er et alternativ til en fængselsstraf på indtil - som hovedregel - 12 måneders fængsel. Med undtagelse af færdselslovsområdet er der ikke, som i nogle af de øvrige nordiske lande, en klar omregningsfaktor mellem længden af den idømte straf og antallet af samfundstjenestetimer (Kyvsgaard 2001).

Sanktionen blev indført som forsøgsordning i 1982 og blev lovfæstet i 1992. Brugen af samfundstjeneste var i begyndelsen meget træg, men ikke mindst på grund af en række lovændringer er det dog lykkes med tiden at få sanktionen

\footnotetext{
* Title in English: Do Offenders Sentenced to Community Service Have Lower Rates of Recidivism than Offenders Sentenced to Imprisonment? Original in Danish.
} 
anvendt i et større omfang. I 2005 blev der afsagt ca. 4100 betingede domme med vilkår om samfundstjeneste, mens der samme år blev idømt ca. 11.500 ubetingede domme. Samfundstjeneste er således ikke længere et ubetydeligt alternativ til fængselsstraf.

Recidivundersøgelser har gennem tiderne vist, at samfundstjenestedømte har væsentligt lavere recidiv end personer, der har afsonet deres dom i fængsel. Det tolkes hyppigt, som om samfundstjeneste er mere effektiv, dvs. mere kriminalpræventiv, end en fængselsstraf. En sammenligning af de samfundstjenestedømtes og fængselsdømtes recidivprocenter kan imidlertid ikke sige noget om sanktionernes indbyrdes effekt, eftersom de to grupper af dømte ikke er sammenlignelige. Sædvanligvis vil samfundstjenestedømte således være mindre kriminelt belastede og have bedre personlige og sociale forhold end dem, der idømmes fængselsstraf. Det er velkendt, at sådanne forhold har en betydning for recidiv.

For at kunne vurdere, om samfundstjenestedømte reelt har lavere recidiv end fængselsdømte, er det derfor nødvendigt at gennemføre en evaluering, hvor der tages højde for forskelle mellem de sammenlignede. Det er en sådan effektevaluering, der er emnet for denne artikel. Artiklen bygger på en ph.d.afhandling, der ud over effektevalueringen også omfatter en procesevaluering. Denne vil ikke blive omtalt her, idet der skal fokuseres på resultaterne af effektevalueringen.

Indledningsvis skal fremhæves, at når der er gennemført en effektevaluering af samfundstjeneste skyldes det, at det giver god mening at forvente, at samfundstjeneste medfører mindre risiko for recidiv end en fængselsstraf. Således må man forvente, at samfundstjeneste i mindre grad end en fængselsstraf ødelægger personens sociale bånd til samfundet - tab af arbejde, bolig, familie m.v. i forbindelse med en afsoning - mens det omvendt også kan formodes, at selve samfundstjenesten - udførelsen af det samfundsnyttige arbejde og kontakten til nye arbejdspladser - kan styrke personen sociale bånd (Hirschi 2004).

\section{Metoder og data}

Ideelt set bør effekten af en sanktion undersøges ved hjælp af et kontrolleret, randomiseret eksperiment. Dvs. at der sker en tilfældig fordeling af de deltagende personer til hhv. eksperimental- og kontrolgruppe. I det aktuelle eksempel vil det betyde, at eksperimentalgruppen får en betinget dom med vilkår om samfundstjeneste og kontrolgruppen en ubetinget dom. Af oplagte grunde har en sådan undersøgelseskonstruktion ikke været mulig. I stedet er der blevet anvendt en kvasi-eksperimentelt design, som - under visse forudsætninger - også er i stand til at give valide resultater. 
Undersøgelsen omhandler to grupper af lovovertrædere. Den ene består af personer, som er dømt for vold, mens den anden består af personer, som er dømt for færdselslovsovertrædelser (spiritus- og promillekørsel, kørsel i frakendelsestiden og kørsel uden førerret). De voldsdømte udgør 4994 personer, hvoraf de 622 har fået samfundstjeneste (eksperimentalgruppe), mens 4372 personer har fået fængselsstraf (kontrolgruppe). Færdselslovsovertrædergruppen omfatter 6411 personer, hvoraf 2768 er blevet idømt samfundstjeneste (eksperimentalgruppe), og de resterende 3643 personer er blevet idømt en ubetinget frihedsstraf (kontrolgruppe). ${ }^{2}$

At effektundersøgelsen angår netop disse to grupper lovovertrædere og ikke andre, som er idømt samfundstjeneste, skyldes, at det for disse to grupper har været muligt at forme en (historisk) kontrolgruppe, som det må antages, at de samfundstjenestedømte kan sammenlignes med. Undersøgelsen kan således siges at benytte sig af en naturlig eksperimentel situation.

For færdselslovsovertræderne er denne situation opstået i forbindelse med en lovændring fra 1. juli 2000, hvor samfundstjeneste blev indført som en mulighed for først og fremmest spritbilister, men også for andre færdselslovsovertrædere (FT 1999-2000 Tillæg A, s. 1125ff). Lovændringen indebar, at personer, der tidligere ville have fået en ubetinget fængselsstraf på - som hovedregel - op til 60 dages fængsel for disse færdselslovsovertrædelser, nu kunne idømmes en betinget dom med vilkår om samfundstjeneste. Samtidig indførtes der mulighed for at idømme spritbilister betinget dom med vilkår om alkoholistbehandling. Inden lovændring havde der imidlertid eksisteret en administrativ ordning med benådning efter deltagelse i en alkoholistbehandling, så det kan antages, at situationen for spritbilister med alkoholproblemer reelt var ret uforandret efter lovændringen. Som det da også ses af figur 1, fik lovændringen umiddelbart effekt på praksis i spritbilismesager, hvor antallet af samfundstjenestedomme har været ret stabilt efter lovændringen. De tilfælde, hvor der efter lovændringen stadig idømmes ubetingede domme, angår de sager, hvor den udmålte straf er på mere end 60 dages fængsel samt de forholdsvis få tilfælde, hvor en person ikke findes egnet til hverken alkoholistbehandling eller samfundstjeneste.

For færdselslovsovertræderne består eksperimentalgruppen derfor af personer, som i en periode af $1 \frac{1}{2}$ år efter lovendringen (1.7.2000-31.12.2001) er idømt samfundstjeneste, mens kontrolgruppen består af dem, som i perioden $1 \frac{1}{2}$ år umiddelbart for lovcendringen (1.1.1999-30.6.2000) blev idømt en ubetinget straf for færdselslovsovertrædelser, og som ikke var omfattet af benådningsordningen for spritbilister. Personer, der måtte overtræde vilkårene for samfundstjeneste og derfor i stedet afsone domme, forbliver i eksperimentalgruppen. 
Figur 1. Den kumulerede fordeling af domme for spiritus- og promillekørsel fordelt efter sanktionens art, 1990-2004.

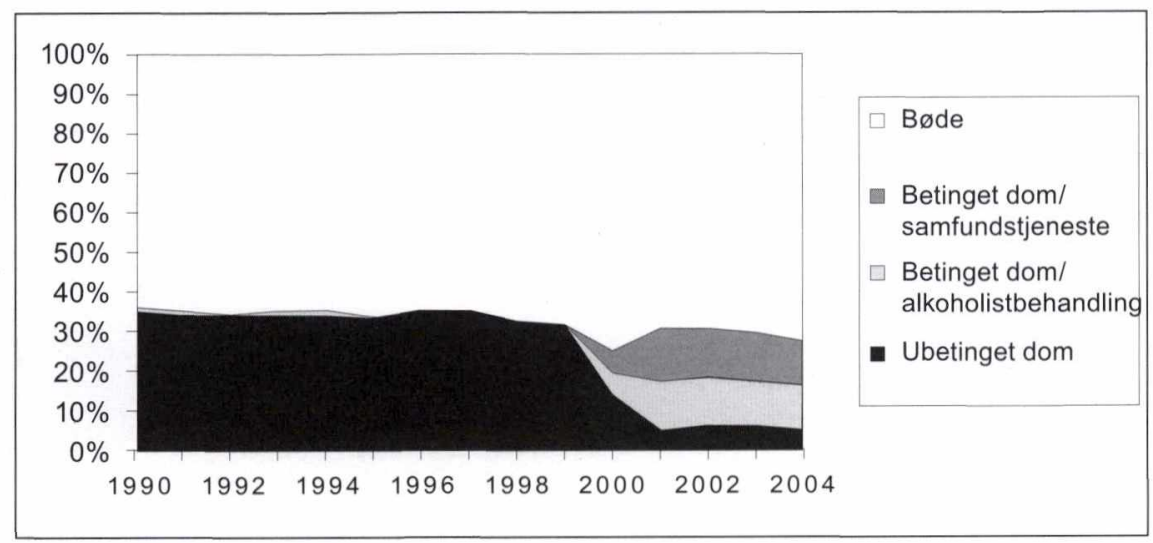

For de voldsdømte er den naturligt eksperimentelle situation opstået som resultat af en praksisændring ved domstolene sidst i 1990'erne. Som det ses af figur 2 er domstolene over et par år begyndt at anvende samfundstjeneste i betydeligt flere sager. ${ }^{3}$ Men antallet af samfundstjenestesanktioner i voldssager havde ligget på omkring 20-30 årligt frem til 1996, voksede dette tal i løbet af et par år til mere end det femdobbelte. Eksperimentalgruppen omfatter derfor de personer, som efter praksiscendringen, nemlig i perioden 1.1.2000-31.12.2001, idømmes samfundstjeneste for vold, mens kontrolgruppen består af personer, som før praksiscendringen, fra 1.1.1997-31.12.1998, blev idømt fængselsstraf for vold. Umiddelbart vurderet er der mindre sammenlignelighed mellem eksperimental- og kontrolgruppe for de voldsdømtes vedkommende end for færdselslovsovertrædernes, idet kontrolgruppen i førstnævnte tilfælde vil omfatte mange voldsdømte, som ikke opfylder kriterierne for at få samfundstjeneste. Dette kan der kun rådes bod på ved at kontrollere for forskelle mellem grupperne.

Undersøgelsen er baseret på registerdata og indeholder - ud over oplysninger om de dømtes kriminelle belastning - også en lang række oplysninger om de dømtes personlige og socioøkonomiske forhold, som kan tænkes at influere på recidivrisikoen. Det drejer sig om følgende forhold: Køn, alder, etnicitet, stofmisbrug, psykisk lidelse, boligens art, uddannelse, arbejde, familietype og indkomst.

For at vurdere, om sanktionstypen har betydning for recidiv, når der kontrolleres for disse baggrundsfaktorer, anvendes i afhandlingen regressions- og overlevelsesanalyser. 
Figur 2. Udviklingen i antallet af samfundstjenestedomme (straffelovskriminalitet).

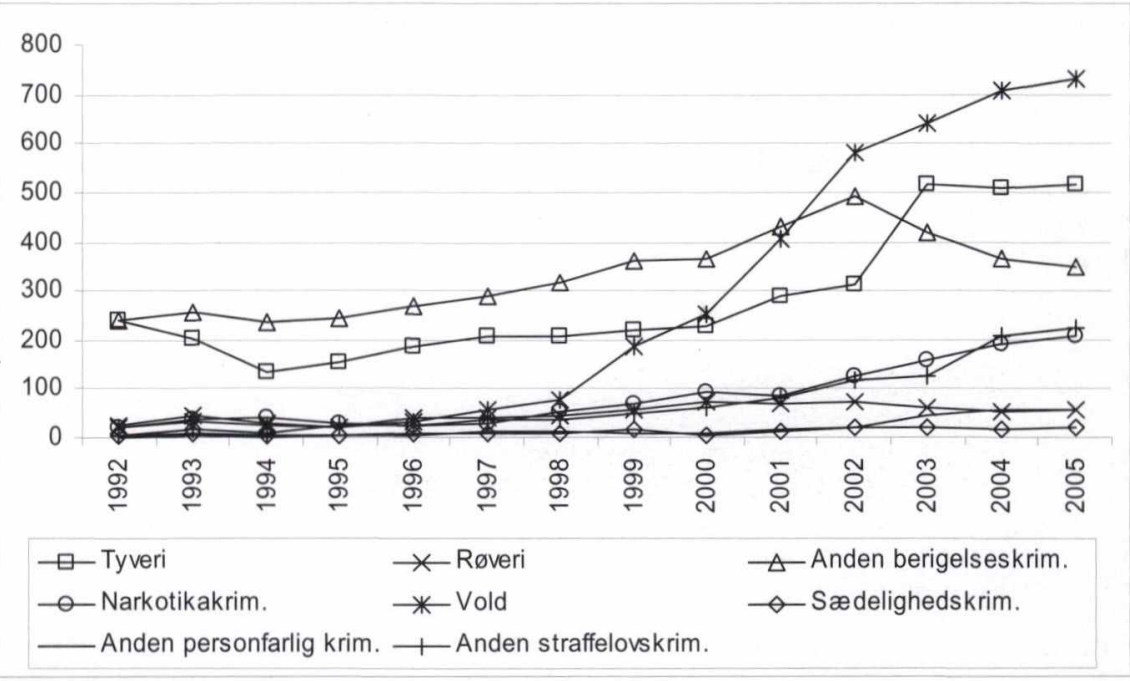

\section{Resultater}

Effektundersøgelsen viser, at det for langt de fleste lovovertræderes vedkommende er andre faktorer end sanktionens art, som har indflydelse på senere recidiv. Når der kontrolleres for baggrundsfaktorerne viser det sig, at personlige faktorer ( $\mathrm{fx}$ alder) har betydning for recidiv, ligesom socioøkonomiske faktorer (fx indkomst og tilknytning til arbejdsmarkedet) har det. Også den tidligere kriminelle belastning har stor betydning for de dømtes recidivrisiko.

Effektundersøgelsen viser imidlertid også, at der er en relativ succes ved at idømme samfundstjeneste i stedet for fængselsstraf, idet analyserne peger på, at samfundstjeneste for nogle grupper eller ved nogle af de anvendte recidivkriterier medfører lavere recidiv end fængselsstraf. For fcerdselslovsovertrcedernes vedkommende viser det sig, at samtlige samfundstjenestedømte dels har lavere recidiv til straffelovskriminalitet end fængselsdømte (33 pct. lavere recidiv), men altså ikke lavere recidiv for så vidt angår færdselslovsovertrædelser. Endvidere viser det sig, at unge færdselslovsovertrædere, som er idømt samfundstjeneste, generelt har lavere recidiv end unge, som har været i fængsel, jf. tabel 1 (36 pct. lavere når recidiv er defineret bredt). Endelig viser undersøgelsen, at omfanget af nye kriminelle forhold er lavere blandt de mandlige recidiverende færdselslovsovertrædere, som har fået samfundstjeneste, end blandt dem, som har været i fængsel. Samlet ses betyder det, at der på ganske mange områder kan påpeges en positiv effekt af at anvende samfundstjeneste i forbindelse med færdselslovsovertrædelser. 
Tabel 1. Sammenligning af risiko for recidiv, fardselslovsovertradere.

\begin{tabular}{|l|l|l|l|l|l|}
\hline & \multirow{2}{*}{$\mathrm{B}$} & \multirow{2}{*}{ Sig. } & \multirow{2}{*}{$\operatorname{Exp}(\mathrm{B})$} & \multicolumn{2}{|c|}{$95 \%$ CI for $\operatorname{Exp}(\mathrm{B})$} \\
\cline { 4 - 6 } & & & & Lower & Upper \\
\hline Fangsel*35-49 år & & & 1 & & \\
Fængsel*15-24 år & 0,872 & 0,000 & 2,391 & 1,996 & 2,864 \\
Fængsel*25-34 år & 0,431 & 0,000 & 1,539 & 1,358 & 1,744 \\
Fængsel*50 år+ & $-0,310$ & 0,001 & 0,733 & 0,611 & 0,880 \\
Samfundstjeneste*35-49 år & $-0,064$ & 0,359 & 0,938 & 0,818 & 1,076 \\
Samfundstjeneste*15-24 år & 0,429 & 0,000 & 1,536 & 1,237 & 1,906 \\
Samfundstjeneste*25-34 år & 0,312 & 0,000 & 1,366 & 1,182 & 1,579 \\
Samfundstjeneste*50 år+ & $-0,172$ & 0,076 & 0,842 & 0,696 & 1,018 \\
\hline
\end{tabular}

For de voldsdømtes vedkommende er en positiv effekt påvist for en mindre gruppe, nemlig de arbejdsløse. For denne gruppe peger undersøgelsen på, at samfundstjeneste medfører end lavere recidiv end en fængselsstraf, jf. tabel 2 (30 pct. lavere recidiv, når recidiv er defineret bredt). Ligeledes viser undersøgelsen, at omfanget af nye kriminelle forhold er lavere blandt de recidiverende arbejdsløse voldsdømte, som har fået samfundstjeneste, end tilfældet er for de recidiverende arbejdsløse voldsdømte, som har været i fængsel.

Tabel 2. Sammenligning af risiko for recidiv, voldsdømte.

\begin{tabular}{|c|c|c|c|c|c|}
\hline & \multirow{2}{*}{$\mathrm{B}$} & \multirow{2}{*}{ Sig. } & \multirow{2}{*}{$\operatorname{Exp}(B)$} & \multicolumn{2}{|c|}{$95 \%$ CI for $\operatorname{Exp}(B)$} \\
\hline & & & & Lower & Upper \\
\hline Faengsel $* I$ arbejde & & & 1 & & \\
\hline Samfundstjeneste*I arbejde & 0,124 & 0,151 & 1,132 & 0,956 & 1,341 \\
\hline Fængsel*Arbejdsløs/uden for arbejdsstyrken & 0,305 & 0,000 & 1,357 & 1,233 & 1,493 \\
\hline Samfundstj.*Arbejdsløs/uden for arbejdsstyr. & $-0,050$ & 0,951 & 0,951 & 0,746 & 1,213 \\
\hline
\end{tabular}

Effektundersøgelsen viser, at der er en positiv effekt af samfundstjeneste for nogle grupper, men har på den anden side altså ikke kunnet vise, at samfundstjeneste overordnet set, dvs. for samtlige dømte, medfører lavere recidiv end fængselsstraf. Én forklaring herpå kunne være, at fængselsstraffen ikke altid ødelægger de dømtes sociale bånd til samfundet, altså har negative, recidivfremmende konsekvenser. En anden forklaring kunne være, at samfundstjenesten ikke i alle tilfælde styrker de dømtes sociale bånd til samfundet og dermed mindsker deres risiko for recidiv.

At fængselsstraffen ikke nødvendigvis har negative konsekvenser kan skyldes, at de dømte, som effektundersøgelsen omfatter, ikke har været i fængsel i så lang tid, at det har medført uoprettelige skader for dem. Det er da også hele 92 pct. af de voldsdømte, som har fået en udmålt straf på under to måneder, mens alle færdselslovsovertræderne har fået udmålt en straf på under 60 dage. 
En fængselsstraf på 1-2 måneder gør ikke nødvendigvis ubodelig skade for en - ellers velfungerende - persons liv. Nogle af de negative konsekvenser af fængselsstraffen må således antages at være tidsafhængige. En kort fængselsstraf vil ikke altid indebære, at man mister sit arbejde, at økonomien går fuldstændig i stykker pga. manglende indtægt, at man mister sin bolig, eller at fængselsopholdet slider så meget på familielivet, at parforholdet går i stykker. På samme måde vil et kort fængselsophold heller ikke nødvendigvis medføre, at den dømte bliver præget af de andre indsatte eller institutionaliseret.

At samfundstjeneste typisk erstatter en kort fængselsstraf anvendes også i en schweizisk effektundersøgelse som forklaring på, at der ikke er nogen signifikant forskel på de dømtes socioøkonomiske situation efter endt afsoning, dvs. hvorfor fængselsstraffen ikke i højere grad forværrer de dømtes situation, end samfundstjeneste gør (Killias, Aebi \& Ribeaud 2000).

Den manglende generelle kriminalpræventive effekt af samfundstjeneste kan som nævnt muligvis også skyldes, at de samfundstjenestedømte ikke har et positivt udbytte af selve samfundstjenesten. Dette forhold må også antages at være tidsafhængigt. En forudsætning for, at de ansatte på samfundstjenestestedet kan påvirke de dømte i en positiv retning, er således, at de opholder sig sammen i en længere periode. Med korte udmålte straffe og dermed også få idømte timer er muligheden for denne sociale påvirkning mere begrænset.

\section{Tolkning af effektundersøgelsens resultater}

Hovedresultaterne i effektundersøgelsen, for så vidt angår risikoen for overhovedet at recidivere, kan sammenfattes til, at samfundstjeneste har en recidivhæmmende effekt for unge færdselslovsovertrædere og arbejdsløse voldsdømte. For både de unge og de arbejdsløse gælder det generelt, at det er grupper, som har en høj recidivrisiko.

For de unges vedkommende skal effekten af samfundstjenestesanktionen nok forklares med, at de unge hermed undgår prisonisering og er udsat for en mindre grad af stigmatisering. Det er altså det forhold, at de unge ikke kommer i fængsel, som kan formodes at have en kriminalpræventiv effekt. De undgår at få kontakt med andre og mere kriminelt belastede lovovertrædere, som kan have en negativ indflydelse på især let påvirkelige unge. Desuden stigmatiseres de i mindre grad af en samfundstjenestedom end af en fængselsstraf. Samfundstjenestedommen optræder i kortere tid på den private straffeattest end en ubetinget dom, hvilket muligvis i særlig grad har betydning for unge, der er i en arbejdsmæssig etableringsfase. Samfundstjenestedommen indikerer endvidere en mindre grad af kriminel belastning og det er således mere tilgiveligt for omgivelserne (venner, familie, arbejdsplads mv.). At lovovertræderen "kun" skal i samfundstjeneste betyder givetvis også noget for den 
dømtes selvopfattelse. Risikoen for sekundær afvigelse vil derfor være mindre ved at udføre samfundstjeneste end ved at komme i fængsel.

Det kan selvfølgelig ikke udelukkes, at den kriminalpræventive effekt af at give samfundstjeneste i stedet for fængselsstraf også kan tilskrives selve samfundstjenesten og den påvirkning, de unge udsættes for på samfundstjenestestedet. For færdselslovsovertrædernes vedkommende drejer det sig dog om meget få timers samfundstjeneste, hvorfor de også har en forholdsvis kort afviklingsperiode. Det forekommer derfor ikke sandsynligt, at dette har haft en klar betydning for den lavere recidivrisiko.

For de arbejdsløses vedkommende skal det kriminalpræventive udbytte derimod nok - i hvert fald til en vis grad - tilskrives selve samfundstjenesten. Denne kan give de arbejdsløse noget, de ikke havde i forvejen. Den kan give dem noget at stå op til, en forpligtelse, en tro på at de kan bruges til noget, en følelse af at de har nogle evner, en oplevelse af at blive respekteret - på trods af kriminalitet - og en anerkendelse af det arbejde, de udfører på samfundstjenestestedet.

Forklaringerne på undersøgelsens kan sammenfattes ved, at samfundstjenesten for de unge synes at vedligeholde deres sociale bånd til samfundet, mens samfundstjenesten for de arbejdsløse antagelig styrker deres sociale bånd til samfundet.

At den kriminalpræventive effekt er tydeligst for de grupper, som har den største recidivrisiko, er i overensstemmelse med de behandlingsprincipper, canadiske forskere har udarbejdet (Andrews 2000). Effektforskningen viser således generelt, at sandsynligheden for at opnå en påviselig effekt er størst med de grupper, som har størst recidivrisiko. Dette indebærer også, at der kan forekomme en effekt for andre grupper, men at denne - pga. deres lave recidivrisiko - er så ringe, at den ikke vil vise sig som en målbar, signifikant forskel.

Ud fra en mere overordnet tolkning af undersøgelsens resultater kan man også spørge sig, om samfundstjeneste overhovedet skal give mindre recidiv end fængselsstraf, for at det kan betegnes som en succes? Eller om det er tilstrækkeligt, at samfundstjeneste ikke medfører højere recidiv end en fængselsstraf? Selv om der her er udgået fra, at samfundstjeneste vil medføre mindre recidiv end fængselsstraf, så er den omvendte hypotese også muligt, idet man kunne forestille sig, at samfundstjeneste i ringere grad end fængselsstraffen afskrækker og inkapaciterer lovovertræderne, hvorfor den vil medføre mere kriminalitet.

Ingen af analyserne viser imidlertid, at samfundstjenere begår mere kriminalitet ved at afsone deres dom i frihed. Der er således ingen risiko forbundet med samfundstjenestesanktionen. De analyser, der er gennemført af omkostningerne ved samfundstjeneste sammenlignet med en fængselsstraf viser samtidig, at der er økonomiske fordele ved sanktionen. ${ }^{4}$ Så længe de samfundstjenestedømte ikke har højere recidivprocent end de fængselsdømte, kan samfundstjeneste - ud fra en costbenefitanalyse - altså betragtes som en succes. 
Også ud fra andre betragtninger kan samfundstjeneste - uanset at der ikke var påvist mindre recidiv - siges at være en succes. Den kvalitative undersøgelse, der er gennemført, viser således tydeligt, at de dømte betragter samfundstjeneste som en mere human straf end fængselsstraf. Da målet må være at påføre så lidt lidelse som muligt for at opnå målet, kan samfundstjeneste også i dette lys ses som en succes.

\section{Samfundstjeneste som meningsfuld straf}

Selv om samfundstjeneste ses som en mere human straf af de straffede, betyder det ikke, at sanktionen ikke har en pønal værdi. Interview med de samfundstjenestedømte viser klart, at kravet om at yde et stykke ulønnet arbejde i fritiden i allerhøjeste grad repræsenterer en straf. Samtidig er det dog en straf, som de dømte foretrækker og opfatter som mere meningsfuld frem for at komme i fængsel. Dette gælder imidlertid ikke blot de dømte, men også de ansatte i den frie kriminalforsorg, samfundstjenestestederne og tilsyneladende også befolkningen generelt,

En retsbevidsthedsundersøgelse fra 2006 viser således, at der i befolkningen er stor opbakning til samfundstjeneste og til andre typer af restorative straffe, herunder konfliktråd eller kompensation til offeret (Balvig 2006a). Mellem 35-61 pct. af befolkningen vil - i de sager retsbevidsthedsundersøgelsen omfatter - idømme en restorativ straf $i$ stedet for en kort fængselsstraf, som er den straf, domstolene vil idømme. Efter at have overværet et rollespil med en konkret (men fiktiv) retssag om gadevold, som ved en domstol vil medføre 40-60 dages ubetinget fængsel, foretrækker 27 pct. af de adspurgte at idømme lovovertræderen en restorativ straf (samfundstjeneste eller konfliktråd), mens det kun er 7 pct., som ønsker personen i fængsel. 3 pct. af de adspurgte mener, at sagen kan afgøres med en bøde. ${ }^{5}$ Den generelle holdning er, at man ikke skal kunne betales sig fra vold. Samfundstjeneste synes derimod at være en rimelig og meningsfuld straf.

De ansatte i Kriminalforsorgen bakker som sagt også op om samfundstjenesteordningen og er samtidig også meget bevidste om at værne om ordningen. De er klar over, at ordningen er afhængig af befolkningens støtte, og at ordningen derfor også er meget sårbar for kritik. Blot én mediebegivenhed om fx dømte, der har planlagt og gennemført en alvorlig forbrydelse, mens de har aftjent samfundstjeneste, kan bevirke, at befolkningens opbakning kan forsvinde. Det er en af grundene til, at KIF ikke vil have flere dømte til at aftjene på samme sted og tid. Ordningens sårbarhed har også betydet, at der særligt under forsøgsordningen blev sat snævre grænser for de dømtes egnethed. Ordningen skulle helst være en succes. Efter ordningen er blevet permanent og i takt med, at der også er kommet flere rummelige samfundstjenestesteder, er egnethedskriterierne dog blevet lempet, men det er stadig en balancegang, idet de dømte skal accepteres af samfundstjenestestederne. 
Det er også en balancegang i forhold til samfundstjenestestederne. Hvis de skal finde det meningsfuldt at være med i ordningen, skal de også have et udbytte af det. Hvis de oplever, at de ikke får den arbejdskraft, de forventer, eller at samfundstjenerne er for ustabile, falder de fra. Kriminalforsorgen forsøger dog at tage hensyn til dette og sikre sig, at samme samfundstjenestested ikke gentagne gange får en "vanskelig" samfundstjener. Også på anden måde forsøger Kriminalforsorgen at efterleve samfundstjenestestedernes ønsker, fx specifikke krav til, hvilken type dømte samfundstjenestestederne vil modtage.

For at samfundstjenesten kan afvikles på en tilfredsstillende måde er det også vigtigt for de dømte, at de oplever det påtvungne arbejde som meningsfyldt. Dette beror i høj grad af, om der reelt er noget, de kan og skal tage sig til, når de er ude og aftjene deres samfundstjeneste. De samfundstjenere, som har oplevet, at der ikke var nok arbejdsopgaver på samfundstjenestestedet, er kritiske over for sanktionen. Derimod synes selve arbejdets karakter ikke at have betydning for, hvordan de oplever samfundstjenesteordningen.

\section{Øget anvendelse af samfundstjeneste som alternativ til frihedsberøvelse}

Det er i dag en udbredt erkendelse af, at der ikke er nogen sammenhæng mellem, hvor meget kriminalitet et samfund har, og hvor meget fængselsstraffen benyttes. "Fangebefolkningens størrelse er ikke skjebne", som Christie udtrykker det (Christie 1997:100). I hvor stort omfang, man vil anvende fængselsstraf som sanktion, er således et spørgsmål om valg.

Finland undergik en interessant udvikling i sidste halvdel af 1900-tallet. I 1950 havde Finland et fangetal, der var fire gange større end i det øvrige Norden. Ved hjælp af diverse tiltag, fx nedkriminalisering af spirituskørsel og tyveri og en større anvendelse af alternativer til frihedsstraf (betinget dom, bøder og samfundstjeneste), havde Finland sidst i 1990'erne nedbragt sit fangetal til niveau som i de andre nordiske lande. Dette var en bevidst strategi. Den kraftige reducering af fangetallet udgjorde en slags naturligt eksperiment med hensyn til at undersøge, hvilken betydning det ville få for kriminalitetsniveauet, at mange lovovertrædere ikke længere skulle afsone deres dom i fængsel. Ville det medføre en stigning i kriminaliteten? Det viste sig, at kriminaliteten steg i den periode, hvor fangetallet blev nedbragt. Det viste sig imidlertid også, at kriminaliteten steg tilsvarende i de andre nordiske lande, som ikke havde gennemgået samme ændring i fangetallet. Stigningen i kriminaliteten syntes altså at være uafhængigt af fangetallet, og det var andre samfundsmæssige faktorer, som bestemte kriminalitetens udvikling (Lappi-Seppälä 1998). ${ }^{6}$ Samme tese bekræftes af Lappi-Seppälä i en nyere artikel, hvor han analyserer sammenhængen mellem fangetal og kriminalitetsudvikling i henholdsvis de nordiske lande og andre vestlige lande. Han konkluderer: "Comparative analyses indicate that differences in 
prisoner-rates can not be explained by differences in crime. Instead, penal severity seems to be closely associated with the extent of welfare provision, differences in income-equality, trust and political-and legal structures" (Lappi-Seppälä 2007).

Andre undersøgelser har vist, at der ingen sammenhæng er mellem straffens størrelse og recidiv (se Balvig 2006b). Ifølge Balvig er der en overordnet effekt af at have et straffesystem. Det vil sige, at bevidstheden om, at der er en konsekvens, hvis man gør noget ulovligt, har en vis præventiv effekt. Men om sanktionen er streng eller mild vil for de fleste vedkommende ikke have nogen betydning for, om man begår kriminalitet. Straffens sikkerhed, dvs. opdagelsesrisikoen, synes i så henseende at have en større betydning end straffens strenghed. I en artikel fra 2006 gennemgår Balvig flere naturlige eksperimenter i Danmark, hvor straffen enten er blevet nedsat eller hævet. Ingen af disse har dog haft betydning for kriminalitetsniveauet (Balvig 2006b).

Samfundstjeneste som alternativ til frihedsberøvelse synes i stort omfang at kunne opfylde de forskellige funktioner, der sædvanligvis nævnes, når straffens tilsigtede virkninger opremses: samfundstjeneste giver mulighed for, at lovovertræderen kan sone sin forbrydelse, samfundstjeneste opfylder befolkningens krav om en passende havn over for lovovertræderen, samfundstjeneste har en almenprceventiv virkning i kraft af at være en konsekvens af en lovovertrædelse, og samfundstjeneste har en individualprceventiv virkning, som i værste fald er på samme niveau som frihedsberøvelse, men i en del tilfælde større.

Den omtalte retsbevidsthedsundersøgelse fra 2006 peger samtidig på, at samfundstjeneste kan anvendes i langt større omfang end for nuværende, idet en stor del af de adspurgte ønsker at give samfundstjeneste til lovovertrædere, som i dag får en ubetinget dom på op til flere måneder. Det synes altså både ud fra befolkningens synsvinkel og ud fra en kriminalpræventiv synsvinkel at være god grund til at udvide anvendelsesområdet for samfundstjeneste.

\section{Forslag til ændring af samfundstjenesteordningen}

På baggrund af den gennemførte proces- og effektevaluering og resultaterne heraf fremsættes i afhandlingen følgende forslag til ændring af den danske samfundstjenesteordning:

\section{Anvendelse som alternativ}

Ordningen bør af principielle grund ændres, så det sikres, at samfundstjeneste kun bliver anvendt som et alternativ til fængselsstraf og ikke et alternativ til betinget dom (dvs. undgå netwidening). Det kan fx gøres ved, at domstolen efter at have idømt en ubetinget dom tager stilling til, om dommen kan konverteres til en betinget dom med vilkår om samfundstjeneste. Det er denne model, der anvendes i Finland. 


\section{Udvidelse af anvendelsesområdet}

På baggrund af effektundersøgelsens resultat foreslås det, at samfundstjeneste i højere grad anvendes i stedet for fængselsstraf over for unge (under 25 år) uanset kriminalitetens art (med mindre særlige forhold taler imod dette). Dette kan ske ved, at alle under 25 år får foretaget en personundersøgelse med henblik på at undersøge, om de er egnet til samfundstjeneste. Det foreslås endvidere, at samfundstjeneste i langt højere grad anvendes overfor personer, som er marginaliseret. I dag anvendes samfundstjeneste som et sikkert kort, dvs. over for rimeligt velfungerende samfundsborgere, som har ringe risiko for recidiv. Det betyder imidlertid, at man næppe opnår nogen stor kriminalpræventiv effekt, fordi de fleste af disse personer under alle omstændigheder ikke ville recidivere. Undersøgelsen peger på, at der vil være større effekt ved at give samfundstjeneste til grupper med en større recidivrisiko. Det anbefales derfor, at egnethedskriterierne for samfundstjeneste udvides, så at også personer med vanskeligere sociale forhold gives denne mulighed.

\section{Større ensartethed i dommeres reaktion på vilkårsovertrcedelser}

Der foreslås endvidere en større ensartethed fra domstolenes side, når vilkårene om samfundstjeneste overtrædes og de dømte indberettes for vilkårsovertrædelser. I dag er der meget forskellig praksis, og reaktionen på indberetning om vilkårsovertrædelser synes at afhænge meget af den enkelte dommers indstilling til spørgsmålet. Især hvis anvendelsesområdet udvides, bør reaktionen være klar. Samfundstjeneste bør have karakter af at være en chance, og en indberetning om vilkårsovertrædelse bør ikke være tomme trusler. Det bør derfor som udgangspunkt føre til, at fængselsstraffen udløses. Det skyldes, at den frie kriminalforsorg på det tidspunkt har forsøgt alt for at få samfundstjenesten til at fungere, og en ny chance om at aftjene samfundstjeneste løser sjældent problemerne.

\section{Mere kontrol og mere tilsyn}

Hvis anvendelsesområdet udvides til at omfatte mere marginaliserede og kriminelt belastede grupper, bør det sikres, at der kommer mere kontrol og mere tilsyn med de dømte, så det er muligt at støtte og motivere dem til at passe afviklingen af samfundstjenesten. Mere kontrol i form af fremmøde på samfundstjenestedet kan anbefales, ligesom hyppigere tilsynssamtaler er ønskværdige. Hyppigheden af tilsynssamtaler bør dog afhænge af den dømtes forsorgsmæssige behov og indebære, at Kriminalforsorgen får flere muligheder for konkret at hjælpe de dømte med fx arbejde, bolig og misbrugsbehandling. Tilsyn, som kun består i kontrol, opfattes som negativt og spild af tid. 
5. Omregningsfaktor mellem udmålt straf og antal samfundstjenestetimer

En undersøgelse har vist store variationer i sammenhængen mellem længden af den udmålte straf og antallet af samfundstjenestetimer, og at straffelovsovertrædere i gennemsnit skal udføre samfundstjeneste i 0,6 time for at undgå én dag i fængsel (Kyvsgaard 1999). Til sammenligning skal færdselslovsovertrædere udføre 1,2-3 timers samfundstjeneste for at undgå én dag i fængsel. Denne forskel forekommer ikke rimelig. Det foreslås derfor, at omregningsfaktoren mellem den udmålte straf og antal samfundstjenestetimer ændres, så forholdet bliver én til én, dvs. én dag i fængsel svarer til én times samfundstjeneste, hvilket svarer til ordningen i Finland og Norge. De nuværende minimums- og maksimumsgrænser på 30 og 240 timer bør dog bevares. Det betyder i praksis, at domme med mindre end én måneds udmålt straf udløser 30 timers samfundstjeneste, og at domme på mere end otte måneders udmålt straf udløser 240 timers samfundstjeneste. Ud over at være mere retfærdigt vil forslaget også kunne skabe gennemskuelighed for de dømte, som hver gang, de har aftjent én samfundstjenestetime, kan tænke på, at det har sparet dem ét døgn i fængsel.

\section{Samfundstjenestestederne}

Et sidste forslag angår muligheden for at kunne benytte flere typer samfundstjenestesteder, herunder også private virksomheder, så samfundstjeneste i højere grad kan fungere som indslusning af arbejdsløse på arbejdsmarkedet. Den nuværende ordning med især mange offentligt støttede samfundstjenestesteder eller steder med et almennyttige formål indebærer, at det er meget sjældent, at en samfundstjener efterfølgende får et arbejde på stedet. En model med private virksomheder som samfundstjenestested for især arbejdsløse personer kunne også være nyttig for arbejdsmarkedet, der i dag i høj grad efterspørger arbejdskraft.

\section{Litteratur}

Andrews, D.A. (2000): "Principles of Effective Correctional Programs". I: Motiuk, L.L. \& Serin, R.C.: Compendium 2000 on Effective Correctional Programming, Correctional Service of Canada.

Balvig, F. (2006a): Danskernes syn på straf. Advokatsamfundet, København.

Balvig, F. (2006b): Virkninger af straf. I: Kyvsgaard, B. (red.): Hvad virker - hvad virker ikke? Kundskabsbaseret kriminalpolitik og praksis. Jurist- og Økonomforbundets Forlag, København.

Christie, N. (1997): Straffens geografi. I: Nordisk Tidsskrift for Kriminalvidenskab, s. $89-102$.

Deloitte \& Touche (1998): Alternativanalyse. Kriminalforsorgens muligheder for alternative opgavevaretagelse. Justitsministeriet, København.

Folketings Tidende 1999-2000 Tillæg A. 
Hirschi, T. (2004) [1969]: Causes of Delinquency. Transactions Publishers, New Brunswick.

Killias, M., Aebi, M., \& Ribeaud, D. (2000): Does Community Service Rehabilitate better than Short-term Imprisonment? Results of a Controlled Experiment. I: The Howard Journal vol. 39 (1) s. 40-57.

Kyvsgaard, B. (1999): Samfundstjeneste i empirisk belysning. I Juristen nr. $4 \mathrm{~s}$. 142-154. DJØFs forlag, København.

Kyvsgaard, B. (2001): Harmoni eller disharmoni mellem de nordiske lande. I: Nordisk Tidsskrift for Kriminalvidenskab vol. 88 (2) s. 89-93.

Lappi-Seppälä, T. (1998): Regulation the Prison Population. Experiences from a Long-Term Policy in Finland. Research Communications 38, National Research Institute of Legal Policy, Helsinki.

Lappi-Seppälä, T. (2007): Penal Policy and Prisoner Rates in Scandinavia. Crosscomparative perspectives in penal severity. I: [Träskman, P. (red.): Rationality and Emotion in European Penal Policy. Nordic Perspectives. Under udgivelse]

\section{Noter:}

1 Susanne Clausen: Samfundstjeneste - virker det? En proces-og effektevaluering af samfundstjenesteordningen i Danmark. Københavns Universitet 2007. Ph. d. projektet er finansieret af Forskningsrådet for Samfund og Erhverv, Forskningsstyrelsen og Det Juridiske Fakultet, Københavns Universitet.

2 Det kan dreje sig om enten en hæftestraf eller en fængselsstraf. I det følgende omtales straffen under ét som fængselsstraf.

3 I afhandlingen drøftes en række mulige forklaringer på ændringen i brug af samfundstjeneste i voldssager, herunder også muligheden for netwidening (dvs. at samfundstjeneste anvendes som alternativ til en betinget dom), men det konkluderes, at den mest sandsynlige forklaring er en egentlig praksisændring som følge af den daværende diskussion af det høje strafniveau i voldssager i Danmark.

4 Konsulentfirmaet Deloitte \& Touche lavede i 1998 for Justitsministeriet en beregning, der bl.a. viste, at mens afsoning af 30 dage i et åbent fængsel kostede ca. 20.000, så var udgifterne til en betinget dom med vilkår om samfundstjeneste i 40 timer det halve (Deloitte \& Touche 1998).

530 pct. foretrækker en betinget dom, 13 pct. foretrækker en behandlingsdom og 10 pct. mener ikke, at der bør være nogen straf eller reaktion overhovedet (Balvig 2006a).

6 Noget lignende er ifølge Balvig sket i Tyskland, hvor man i 1969 i det daværende Vesttyskland gennemførte en reform, der betød, at mere end to tredjedele af frihedsstraffene på under seks måneder blev ændret til bøder. Denne ændring påvirkede imidlertid ikke kriminalitetsniveauet. Derimod viste det sig, at dem, som havde afsonet en kort frihedsstraf, havde højere recidiv end dem, som fik bøder (Balvig 2006b).

Adresse:

Justitsministeriets Forskningsenhed

Slotsholmsgade 10

1216 København K. 